\title{
Crop coefficient approaches based on fixed estimates of leaf resistance are not appropriate for estimating water use of citrus
}

\author{
Taylor $\mathrm{NJ}^{1^{*}}$, Mahohoma $\mathrm{W}^{1}$, Vahrmeijer $\mathrm{JT}^{1,2}$, Gush $\mathrm{MB}^{3}$, Allen $\mathrm{RG}^{4}$ and Annandale \\ $\mathrm{JG}^{1}$ \\ ${ }^{1}$ Department of Plant Production and Soil Science, University of Pretoria, Private Bag X20, Hatfield \\ 0028, South Africa \\ ${ }^{2}$ Citrus Research International, P.O. Box 28, Nelspruit 1200, South Africa \\ ${ }^{3}$ CSIR - Natural Resources and the Environment, Hydroscience Research Group, P.O. Box 320, \\ Stellenbosch 7599, South Africa \\ ${ }^{4}$ Biological and Agricultural Engineering and Civil Engineering, University of Idaho, 3793 N3600 E, \\ Kimberley, ID, 83341, USA \\ " corresponding author \\ Email: nicolette.taylor@up.ac.za \\ Phone: +27 124203666
}

Fax: +27 124204120

\section{Abstract}

The estimation of crop water use is critical for accurate irrigation scheduling and water licenses. However, the direct measurement of crop water use is too expensive and time consuming to be performed under all possible conditions, which necessitates the use of water use models. The FAO- 56 procedure is a simple, convenient and reproducible method, but as canopy cover and height vary greatly among different orchards, crop coefficients may not be readily transferrable from one orchard to another. Allen and Pereira (2009) therefore incorporated a procedure into the FAO-56 approach which estimates crop coefficients based on a physical description of the vegetation and an adjustment for relative crop stomatal control over transpiration. Transpiration crop coefficients derived using this procedure and fixed values for citrus, did not provide good estimates of water use in three citrus orchards. However, when mean monthly leaf resistance was taken into account, 
good agreement was found with measured values. A relationship between monthly reference evapotranspiration and mean leaf resistance provided a means of estimating mean leaf resistance which estimated transpiration crop coefficients with a reasonable degree of accuracy. The use of a dynamic estimate of mean leaf resistance therefore provided reasonable estimates of transpiration in citrus.

\section{Introduction}

Citrus is one of the most important fruit tree crops in the world, with over 5.4 million ha currently under cultivation. Many of these orchards are planted in semi-arid regions or subtropical regions where rainfall is seasonal and as a result the vast majority of these evergreen, perennial orchards are under irrigation. This represents a significant irrigation requirement and with more pressure being placed on agriculture to reduce water use and with the increase in pollution of natural water resources, it is becoming increasingly important to accurately estimate water use of cultivated crops. Citrus is also an important crop in South Africa, where an additional driver for improved water management is an increase in electricity tariffs, where growers aim to schedule irrigation more efficiently to reduce pumping costs. It was as a result of the need for more definitive information on water use of fruit tree crops that the Water Research Commission of South Africa solicited, managed and funded a project for determining fruit tree water use, with co-funding from the South African Department of Agriculture, Forestry and Fisheries (Water Research Commission 2008).

Water use measurements are too expensive and time consuming to perform in all crops under all conditions and as a result various water use models have proved very useful in extrapolating measured data and predicting water use. The crop coefficient $\left(K_{\mathrm{c}}\right)$ approach described by Allen et al. (1998) has been used extensively in irrigation water management and is currently considered the standard method for determining crop water use, due largely to its relative simplicity. However, in tree crops, a linear relationship between the evapotranspiration (ET) from a short, smooth and uniform grass surface and a tall, very rough, clustered orchard canopy may not always hold true (Annandale and Stockle 1994; Testi et al. 2004). This often means 
Table 1. Seasonal crop coefficients determined in citrus orchards across the growing regions of the world

\begin{tabular}{|c|c|c|c|c|c|c|c|c|c|c|c|}
\hline \multirow[t]{2}{*}{ Reference } & \multirow[t]{2}{*}{ Region } & \multirow{2}{*}{$\begin{array}{c}\text { ET } \\
\text { method }\end{array}$} & \multirow{2}{*}{$\begin{array}{c}f_{c} \\
(\%)\end{array}$} & \multicolumn{4}{|c|}{$\mathrm{ET}_{\mathrm{o}}\left(\mathrm{mm}\right.$ day $\left.^{-1}\right)$} & \multicolumn{4}{|c|}{$K_{\mathrm{c}}$} \\
\hline & & & & Summer $^{b}$ & Autumn & Winter & Spring & Summer & Autumn & Winter & Spring \\
\hline $\begin{array}{l}\text { Marin and Angelocci } \\
\text { (2011) }\end{array}$ & Brazil & $\begin{array}{l}\text { Aerodynamic } \\
\text { method }\end{array}$ & & 4.4 & & 2.7 & & 0.7 & & 0.26 & \\
\hline $\begin{array}{l}\text { Villalobos et al. } \\
\text { (2009) }\end{array}$ & Spain & $\begin{array}{l}\text { Eddy } \\
\text { covariance }\end{array}$ & & & 4.99 & & 5.88 & & 0.44 & & 0.43 \\
\hline $\begin{array}{l}\text { Snyder and } \\
\text { O'Connell (2007) }\end{array}$ & USA & $\begin{array}{l}\text { Surface } \\
\text { renewal }\end{array}$ & $66-70$ & 6.27 & 3.03 & 1.10 & 4.13 & 1.00 & 1.07 & 1.15 & 1.13 \\
\hline Alves et al. (2007) & Brazil & Lysimeter & $22-42$ & 4.40 & 3.49 & 2.90 & 4.30 & 1.13 & 1.02 & 0.60 & 0.86 \\
\hline $\begin{array}{l}\text { García Petillo and } \\
\text { Castel (2007) }\end{array}$ & Uruguay & Water balance & 50 & 4.99 & 1.77 & 1.45 & 4.06 & 0.64 & 0.77 & 0.84 & 0.83 \\
\hline Rana et al. (2005) & Italy & $\begin{array}{l}\text { Eddy } \\
\text { covariance }\end{array}$ & & & & & & 1.04 & 0.77 & 0.81 & 1.16 \\
\hline Castel (1997) & Spain & Lysimeter & 27 & 4.78 & 2.69 & 2.06 & 3.75 & 0.40 & 0.62 & 0.42 & 0.28 \\
\hline Castel et al. (1987) & Spain & Water balance & 70 & 4.93 & 2.57 & 1.53 & 3.43 & 0.70 & 0.77 & 0.65 & 0.61 \\
\hline Rogers et al. (1983) & USA & Water balance & 70 & 4.1 & 3.13 & 2.37 & 4.37 & 1.04 & 1.01 & 0.93 & 0.81 \\
\hline Hoffman et al. (1982) & USA & Water balance & 70 & 7.7 & 4.1 & 2.27 & 5.27 & 0.85 & 0.83 & 0.77 & 0.80 \\
\hline $\begin{array}{l}\text { Green and Moreshet } \\
\text { (1979) }\end{array}$ & $\begin{array}{l}\text { South } \\
\text { Africa }\end{array}$ & Lysimeter & 100 & 6.86 & 3.15 & 2.62 & 4.59 & 0.80 & 1.28 & 0.79 & 0.62 \\
\hline $\begin{array}{l}\text { van Bavel et al. } \\
\text { (1967) }\end{array}$ & USA & Water balance & & 7.91 & 3.77 & 2.25 & 6.30 & 0.62 & 0.72 & 0.48 & 0.48 \\
\hline
\end{tabular}

${ }^{\text {a }}$ Seasons were determined according to the equinoxes and solstices, with each season comprising 3 months. Values presented are the average for each three month period. 
that $K_{\mathrm{c}}$ values derived in one location may not be readily transferable to other locations, which limits the extrapolation of such data to different climatic zones, with different orchard management practices. This is evident in the wide range of published $K_{\mathrm{c}}$ values for citrus (Table 1), where variation is attributed to variety, rootstock, tree spacing, canopy height, ground cover, tillage, leaf area index, method of estimating reference evapotranspiration, microclimate, irrigation method and frequency and method of measuring crop evapotranspiration (Snyder and O'Connell 2007; Naor et al. 2008). Snyder and O'Connell (2007) illustrate the site specific nature of their citrus crop coefficients by including the following proviso that these recommendations are for "clean-cultivated, microsprinkler irrigated, mature orchards in the San Joaquin Valley of California or in regions with similar climatic conditions". As much of the variation in $K_{\mathrm{c}}$ values is also attributed to evaporation from the soil, as a result of different irrigation systems and rainfall patterns (Villalobos et al. 2009), the measurement of transpiration should allow improved estimates of transpiration crop coefficients $\left(K_{t}\right)$ of citrus orchards and reduce the need to perform costly measurements of tree water use under different environmental conditions and management practices. Villalobos et al. (2013) also stress the importance of determining transpiration, as this is related to tree assimilation and productivity and it allows accurate partitioning of ET between transpiration and soil evaporation.

In an attempt to make crop coefficients more transferrable between different orchards, Allen and Pereira (2009) developed a procedure for estimating crop coefficients where vegetation density and height varies between orchards. These authors found that under such conditions, $K_{\mathrm{c}}$ and basal crop coefficient $\left(K_{\mathrm{cb}}\right)$ values can be estimated more accurately by taking into account fraction of ground covered or shaded by the vegetation, the height of the vegetation and the degree of stomatal regulation under wet soil conditions. An adjustment can also be made for climate by taking into account the average relative humidity and wind speed of the climate, which accounts for the differences in roughness between the grass reference surface and the tall orchard canopy. The aim of this paper was therefore to evaluate this procedure for the derivation of orchard specific $K_{\mathrm{t}}$ values in three citrus orchards in different climatic regions of South Africa (summer and winter rainfall regions), by comparing derived $K_{\mathrm{t}}$ values with actual $K_{\mathrm{t}}$ values determined from transpiration measurements using sap flow. $K_{\mathrm{t}}$ values, as suggested by Villalobos et al. (2013), 
were chosen as $K_{\mathrm{cb}}$ includes some evaporation when the soil surface is dry and only transpiration was measured in this study.

\section{Materials and Methods}

\section{Experimental Site}

Measurements of citrus [Citrus sinensis (L.) Osbeck] water use were conducted in three orchards in the summer and winter rainfall regions of South Africa over three consecutive seasons (Table 2). Measurements in the summer rainfall region were conducted in the Limpopo Province at Moosrivier Farm (Schoeman Boerdery Group) near Groblersdal, in commercial orchards planted with "Delta" Valencia $\left(25^{\circ} 02^{\prime \prime}\right.$ 32.69" S and $29^{\circ} 22^{\prime \prime} 09.76 "$ E, 900 m.a.s.I., orchard area of 11 ha) and „Bahianinha" Navel trees ( $25^{\circ} 01^{\prime \prime} 42.53^{\prime \prime \prime \prime} \mathrm{S}$ and $29^{\circ} 22^{\prime \prime} 46.16^{\prime \prime \prime \prime} \mathrm{E}, 870$ m.a.s.l., orchard area of 2.4 ha) in the 2008/09 and 2009/10 seasons. The area receives an average annual rainfall of $535 \mathrm{~mm}$ and has average minimum and maximum temperatures of $12^{\circ} \mathrm{C}$ and $25^{\circ} \mathrm{C}$. In the winter rainfall region measurements were conducted at Patrysberg Farm in the Western Cape Province $\left(32^{\circ} 27^{\prime \prime} 15.43^{\prime \prime \prime \prime} \mathrm{S}\right.$ and $18^{\circ} 58^{\prime \prime} 3.58^{\prime \prime \prime \prime} \mathrm{E}, 149$ m.a.s.l., orchard area 3.9 ha) near Citrusdal, in a commercial orchard planted with „Rustenburg" Navels in the 2010/11 season. The area receives an average annual rainfall of $200 \mathrm{~mm}$ and has average minimum and maximum temperatures of $10^{\circ} \mathrm{C}$ and $24^{\circ} \mathrm{C}$.

The 11 year-old "Delta" Valencia trees, in the summer rainfall region, were grafted on "Swingle" citrumelo rootstocks and were planted in 1997, in a north-south orientation $\left(0^{\circ} \mathrm{N}\right)$. Tree spacing was $5.5 \times 2.75 \mathrm{~m}$ and every alternate tree was "sandwich" pruned, meaning this tree was pruned narrower every year to allow the trees on either side to grow into the pruned space. "Sandwich" pruned trees are removed once the trees on either side have reached an adequate size as determined by the grower. Average tree height was $4.1 \mathrm{~m}$ and average effective fraction of ground covered or shaded by vegetation $\left(f_{\mathrm{c}}\right.$ eff) was 0.6 (calculated as described in the section on the estimation of crop coefficients and was an average for the season). 


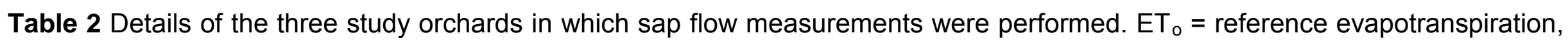
$f_{c}$ eff is the effective fraction of ground covered or shaded by the vegetation at solar noon

\begin{tabular}{|c|c|c|c|}
\hline Orchard & 'Delta' Valencia & 'Bahianinha' Navel & 'Rustenburg' Navel \\
\hline Location & Groblersdal & Groblersdal & Citrusdal \\
\hline GPS co-ordinates & $25^{\circ} 02^{\prime} 32.69^{\prime \prime} \mathrm{S}, 29^{\circ} 22^{\prime} 09.76^{\prime \prime} \mathrm{E}$ & $25^{\circ} 01^{\prime} 42.53^{\prime \prime} \mathrm{S}, 29^{\circ} 22^{\prime} 46.16^{\prime \prime} \mathrm{E}$ & $32^{\circ} 27^{\prime} 15.43^{\prime \prime}, 18^{\circ} 58^{\prime} 3.58^{\prime \prime} \mathrm{E}$ \\
\hline End & $30-07-2009$ & $30-06-2010$ & $12-08-2011$ \\
\hline Duration (days) & 364 & 301 & 365 \\
\hline Age (years) & 11 & 6 & 14 \\
\hline$f_{\mathrm{c} \text { eff }}$ & 0.60 & 0.63 & 0.88 \\
\hline Height (m) & $4.1 \mathrm{~m}$ & $2.3 \mathrm{~m}$ & $3.3 \mathrm{~m}$ \\
\hline$E T_{0}(m m)^{a}$ & 1668 & 1423 & 1528 \\
\hline Rainfall $(\mathbf{m m})^{\mathrm{a}}$ & 579 & 518 & 203 \\
\hline Irrigation (mm) ${ }^{a}$ & 925 & 261 & 600 \\
\hline
\end{tabular}

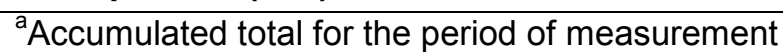


Yield for the 2008/09 season was disappointing (28 $\mathrm{t} \mathrm{ha}^{-1}$ ) due to fruitlet abscission during hot and dry conditions shortly after fruit set. The orchard was drip irrigated with one line per tree row with pressure compensating emitters with a discharge of 2 $\mathrm{L} \mathrm{h}^{-1}$ spaced $1 \mathrm{~m}$ apart. Typically the orchard received irrigation on a daily basis, with two to three $2 \mathrm{~h}$ pulses per day. The soil texture was a sandy loam, with an average of $7-12 \%$ clay in the top metre.

The 6 year-old "Bahianinha" Navel trees, also in the summer rainfall region, were grafted on "Carrizo" citrange rootstocks and were planted in 2003 on ridges. The row orientation was $51^{\circ} \mathrm{ENE}$, with north being $0^{\circ}$. Tree spacing was $6 \times 2 \mathrm{~m}$, with trees pruned to a constant average height of $2.3 \mathrm{~m}$ and width within the row of $1.8 \mathrm{~m}$ every year after harvest, such that a complete hedgerow was not formed. Average tree height was $2.5 \mathrm{~m}$ and average $f_{\mathrm{c} \text { eff }}$ was 0.63 . Yield for the $2009 / 10$ season was well below the average for this orchard $\left(15 \mathrm{t} \mathrm{ha}^{-1}\right)$, as a result of poor flowering associated with a late harvest in the previous season. The orchard was drip irrigated with one line per tree row using pressure compensating emitters spaced $1 \mathrm{~m}$ apart with a discharge of $2.3 \mathrm{~L} \mathrm{~h}^{-1}$. Typically the orchard received irrigation on a daily basis, with three to four $1 \mathrm{~h}$ pulses per day. The soil texture was a sandy loam with an average of $5-10 \%$ clay in the top metre.

The 14 year-old „Rustenburg" Navel trees, in the winter rainfall region, were grafted on "Troyer" citrange rootstocks and were planted in 1996 on ridges. The row orientation was $79^{\circ}$ ENE. Tree spacing was $5 \times 2.5 \mathrm{~m}$ with trees being pruned shortly after harvest to a height of $3.2 \mathrm{~m}$, with selective limb removal, according to the industry standards of the production area. Average tree height was $3.3 \mathrm{~m}$ and average $f_{\mathrm{c}}$ eff was 0.88 . Yield for the $2010 / 11$ season was $75 \mathrm{t} \mathrm{ha}^{-1}$. The orchard was drip irrigated, with two drip lines per tree row using pressure compensating emitters spaced $0.8 \mathrm{~m}$ apart with a discharge of $1.8 \mathrm{~L} \mathrm{~h}^{-1}$. Typically the orchard was irrigated on a daily basis, with one 2-3 h pulse per day. The soil texture was a sandy loam with an average of $5-10 \%$ clay in the top metre.

All orchards were managed according to GLOBALG.A.P standards and were selected based on a history of excellent production and on advice received from extension officers of Citrus Research International. Irrigation scheduling was 
performed by the growers by monitoring soil water content with capacitance probes and adjusting a daily irrigation schedule to maintain the soil water content within limits determined based on soil texture and experience in each irrigation block. Profile pits were dug at the start of the measurement period in each orchard to install soil water monitoring equipment and at this time root distribution and any evidence of waterlogging was visually assessed. None of the orchards showed any typical mottling of the soil associated with waterlogging and there was ample evidence of a healthy root system. Daily irrigation volumes were determined by placing two tipping bucket rain gauges under drippers in each orchard. In addition, in line water meters were read every two weeks and provided a check on volumes estimated using the tipping buckets. In Groblersdal the area along the tree rows, with a width of $1 \mathrm{~m}$, was kept clear of weeds through the use of herbicides, with a grass cover between rows. In Citrusdal the orchard was mostly free of vegetation between rows, largely as a result of a significant dry period in summer.

Sap flow and Transpiration

Sap flow measurements were performed using the heat ratio method as described by Burgess et al. (2001) on four trees in each orchard at Groblersdal and six trees at Citrusdal. Trees were selected in the centre of each block. In the "Delta" Valencia orchard the four sample trees included two sandwich pruned trees. Four heat pulse probe sets were inserted to four different depths in each tree trunk to account for the radial variation in sap flux within the conducting sapwood (Table 3). These probe sets were inserted above the rootstock in the scion and below the first branch, with the probes being equally spaced around the trunk and randomly arranged, taking care to avoid any abnormalities in the trunk. Each probe set consisted of two Type T (copper/constantan) thermocouples (embedded in $2 \mathrm{~mm}$ outside diameter PFTE tubing) placed equidistantly $(0.5 \mathrm{~cm})$ upstream and downstream of the stainless steel heater probe $(1.8 \mathrm{~mm})$. The heat pulse velocity $\left(V_{h}\right)$ in $\mathrm{cm} \mathrm{h}^{-1}$ for each probe set was calculated following Marshall (1958) as:

$$
V_{h}=\frac{k}{x} \ln \left(\frac{v_{1}}{v_{2}}\right) * 3600
$$


Table 3 Trunk circumference $(\mathrm{mm})$ and probe insertion depths for trees selected for sap flow measurements in the three orchards.

\begin{tabular}{lll}
\hline Orchard & Stem circumferences $(\mathbf{m m})$ & Insertion depths of probes $(\mathbf{m m})$ \\
\hline 'Delta' Valencia & $327 ; 382 ; 394 ; 477$, & $10 ; 20 ; 30 ; 40$ \\
& & \\
'Bahianinha' Navel & $313 ; 346 ; 306$ & $7 ; 20 ; 30 ; 40$ \\
& 222 & $7 ; 14 ; 22 ; 30$ \\
& $345 ; 280$ & $8 ; 15 ; 25 ; 30$ \\
'Rustenburg' Navel & $392 ; 444 ; 384 ; 442$ & $10 ; 18 ; 30 ; 40$ \\
\hline
\end{tabular}


where $k$ is the thermal diffusivity of green (fresh) wood (assigned a nominal value of $2.5 \times 10^{-3} \mathrm{~cm}^{2} \mathrm{~s}^{-1}$, (Marshall 1958)), $x$ is distance in $\mathrm{cm}$ between the heater and either the upper or lower thermocouple, $v_{1}$ and $v_{2}$ are increases in temperature after the 0.4 $s$ heat pulse is released (from initial temperatures) as measured by the upstream and downstream thermocouples and 3600 converts seconds to hours. Heat pulse velocities were measured and logged on an hourly basis using a CR10X or CR1000 data logger and an AM16/32B multiplexer (Campbell Scientific Ltd, Logan, Utah, USA). Conversion of heat pulse velocities to sap flux densities, taking into account wounding, were performed according to Burgess et al. (2001). Whole stem sap flux (assumed to be equal to transpiration) was calculated as a product of sap flux density and weighted sapwood cross-sectional area represented by each probe set. The presence of heartwood was determined by taking wood cores with an incremental borer. As there was no change in colour of the wood from the outside (youngest wood) to the centre of the core (oldest wood) in any of the samples taken in each orchard, it was assumed that no heartwood was present. Integrated volumetric sap flow of the individual trees $\left(\mathrm{L} \mathrm{day}^{-1}\right)$ was converted to transpiration $\left(\mathrm{mm}\right.$ day $\left.^{-1}\right)$ using the ground area allocated to each tree in the orchard i.e. $15.125 \mathrm{~m}^{2}$ in the "Delta" Valencia orchard, $12 \mathrm{~m}^{2}$ in the ,Bahianinha" Navel orchard and $12.5 \mathrm{~m}^{2}$ in the „Rustenburg" Navel orchard. Transpiration of the „Delta" Valencia orchard was calculated as an average of the sample trees as a result of the sandwich pruning method adopted in this orchard, which resulted in a significantly smaller canopy in every second tree. In the other two orchards orchard transpiration was calculated as a weighted average of sampled trees as suggested by Hultine et al. (2010), based on a stem circumference survey at the start of the study and the consistent relationship between seasonal water use and stem circumference (Fig. 1).

Orchard transpiration was calibrated against micrometeorological measurements of ET during periods of negligible evaporation from the soil and cover crop in the "Delta" Valencia orchard using a empirically determined wound correction coefficient, which was determined to be $3.2 \mathrm{~mm}$ (Fig. 2). Although calibration focused on the wound width, it will also account for possible uncertainties in sapwood moisture content, sapwood density and the upscaling from individual trees to orchard scale. Similar sap flow calibrations have been performed by Williams et al. (2004) in an olive orchard assuming evaporation from the soil is negligible and by using a combination 


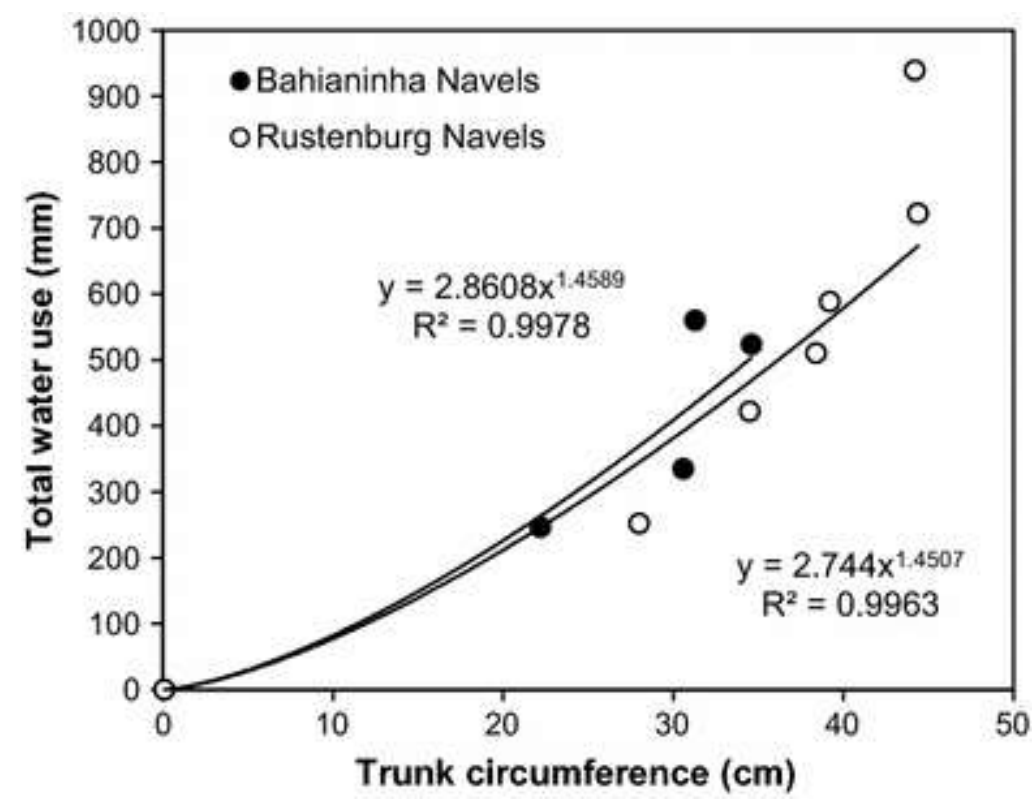

Fig. 1 : Relationship between trunk circumference and seasonal water use for the „Bahianinha" and „Rustenburg"Navel orchards

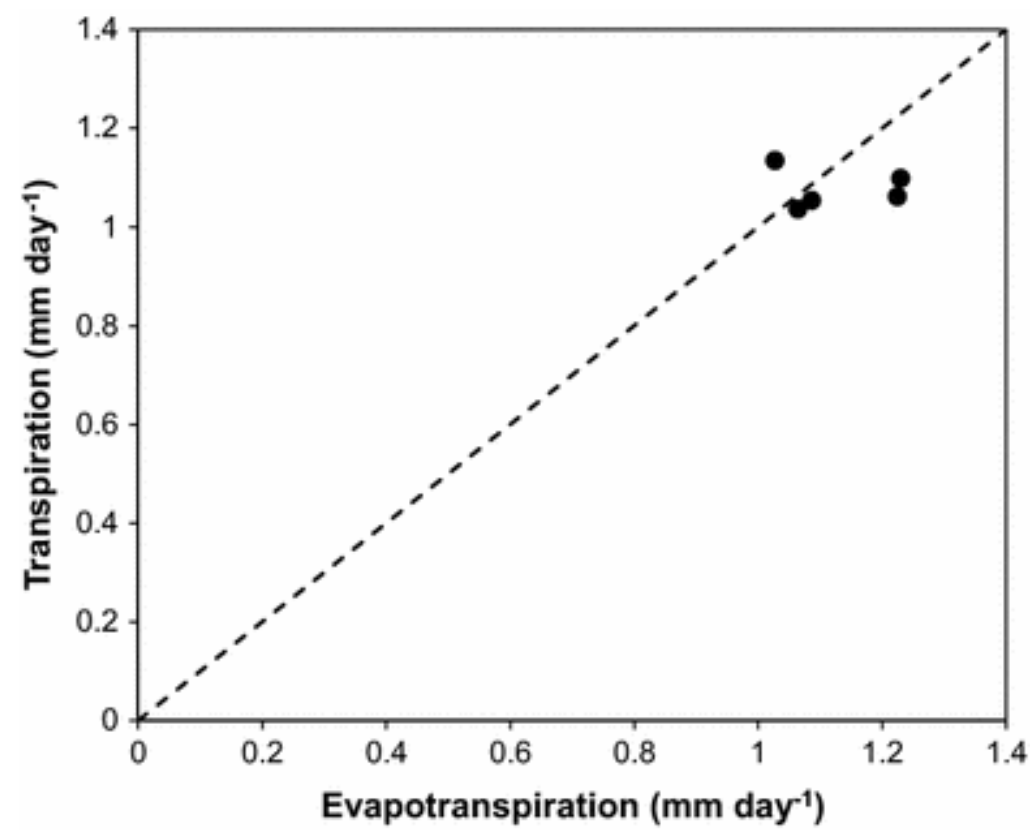

Fig. 2 : Comparison of daily crop evapotranspiration, measured with an eddy covariance system, with calibrated transpiration, determined using the heat ratio method, for the autumn measurement window in the „Delta"Valencia orchard in May 2009, when evaporation from the soil was negligible

of eddy covariance and micro-lysimeter measurements in a vineyard (PobleteEcheverría et al. 2012), pear orchard (Conceição and Ferreira 2008) and broadleaved forest (Köstner et al. 1992). The advantage of this method of calibration is that it can be performed in field without the use of weighing lysimeters, which although ideal, are expensive to install and require a number of years for the tree planted in the lysimeter to reach an adequate size for measurement. It is also non- 
destructive as compared to stem perfusion and potometer calibration methods. However, eddy covariance measurements can be associated with some degree of error, but these can be assessed and minimised through careful analysis of the data (Allen et al. 2011a). In addition, whilst water use of a single tree is determined in a lysimeter, eddy covariance measurements represent a much larger area and a number of trees. The size and the shape of the area sampled are not fixed in time and vary with wind speed and direction (Horst and Weil 1992; Baldocchi 1997). However, there was adequate fetch and as measurements in this study were conducted in a large orchard of clonal trees this variation is expected to be minimal. As the need for calibration arises largely due to the variation in the distribution of sap conducting vessels within the sapwood (Green and Clothier 1988), which is assumed to be conservative for a species, a single calibration for a species for a specific sap flow technique should be sufficient (Smith and Allen 1996) and it should be transferable to other citrus orchards. In addition, a single calibration should also be sufficient as Pernice et al. (2008), Fernández et al. (2001), Giorio and Giorio (2003) and Poblete-Echeverría et al. (2012) showed no reduced sensitivity due to injury effects caused by probe implantation over a period of 2 months to 3 years.

Micrometeorological measurements

Micrometeorological measurements for the estimation of ET, via the eddy covariance method, were performed for short window periods in each orchard, due to restrictions on the availability of equipment. Calibration of the heat ratio method for citrus was performed during a window period in May 2009 in the "Delta" Valencia orchard, when no rainfall occurred, the grass cover between the tree rows was dormant and evaporation from the soil was considered negligible. Fluxes of latent (LE) and sensible heat $(H)$ were measured with an extended open path eddy covariance (OPEC) system, comprising a CSAT3 three-dimensional sonic anemometer (Campbell Scientific Inc., Logan, Utah, USA) and an LI-7500 open path infrared gas analyser (LiCor Inc., Lincoln, Nebraska, USA), which was mounted on a lattice mast $6.2 \mathrm{~m}$ above the soil surface (2 $\mathrm{m}$ above the canopy). Upwind fetch of the prevailing northerly winds was $300 \mathrm{~m}$. Measurements were sampled at a frequency of $10 \mathrm{~Hz}$ and logged on a CR5000 data logger (Campbell Scientific Inc., 
Logan, Utah, USA). Air temperature and humidity were measured using a Vaisala HMP45C temperature and humidity probe (Vaisala Oyj, Vantaa, Finland). Net radiation $\left(R_{n}\right)$ was measured using two net radiometers (Model 240-110 NR-Lite, Kipp \& Zonen, Delft, Netherlands), one above the trees, $7.1 \mathrm{~m}$ above ground, and the other between the rows, placed $8.0 \mathrm{~m}$ from the ground surface. Accuracy of the $R_{n}$ measurements were compared against $R_{n}$ estimated using standard equations (Allen et al. 1998) based on solar radiation from an automatic weather station (AWS) located at the site (Allen et al. 2011b). Four soil heat flux plates (model HFT-S, REBS, Seattle, Washington, USA) were used to measure soil heat flux (G) at a depth of $80 \mathrm{~mm}$ under the trees and between the rows, and four TCAV-L soil temperature averaging probes (Campbell Scientific Inc., Logan, Utah, USA) at depths of 20 and $60 \mathrm{~mm}$ were used to calculate the heat stored above the plates. Volumetric soil water content in the first $60 \mathrm{~mm}$ of the soil surface was measured using a time domain reflectometer (CS616, Campbell Scientific Inc., Logan, Utah, USA). These sensors were connected to a CR23X datalogger (Campbell Scientific Inc., Logan, Utah, USA) and measurements were performed at $10 \mathrm{~Hz}$ frequency and averages obtained every 30 minutes. Energy balance closure for the measurement period varied between 0.3 and $6 \%$, indicating good closure (Fig. 3).

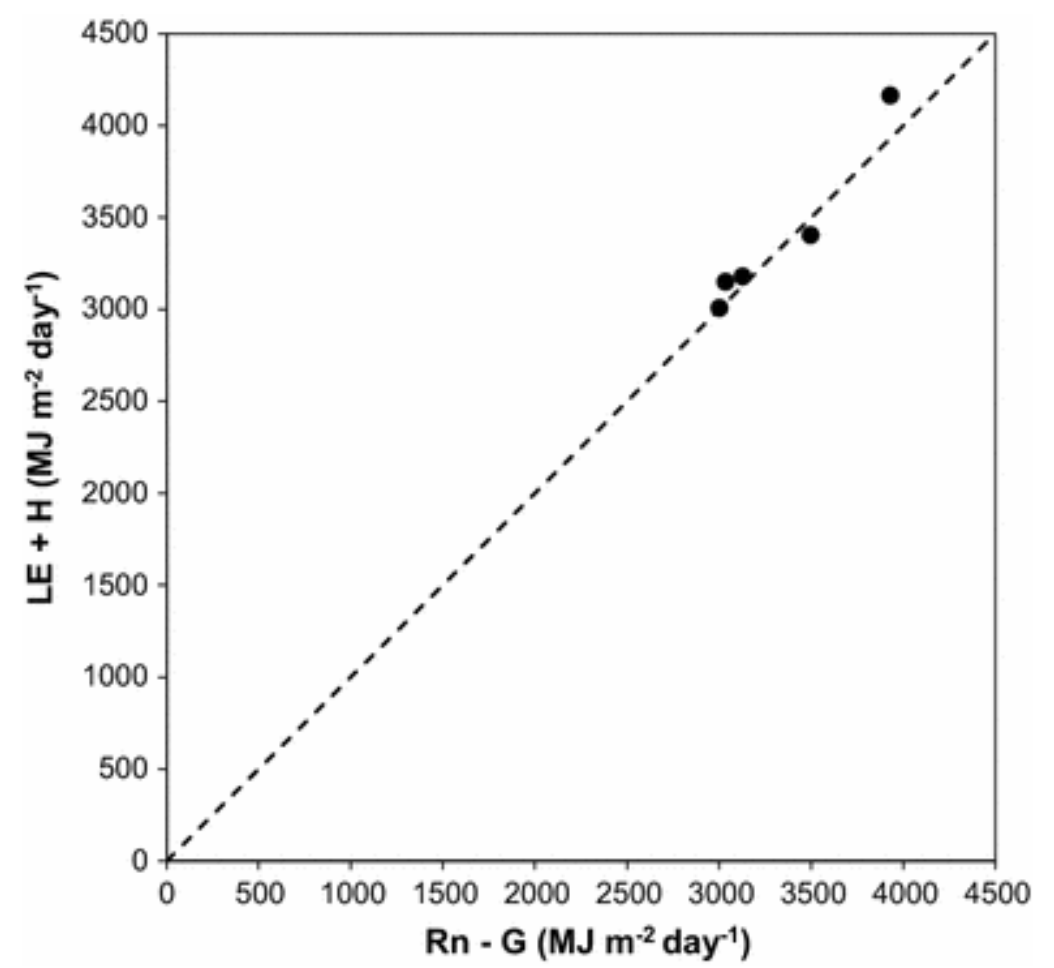

Fig. 3 : Daily energy balance closure for the eddy covariance measurements in the „Delta" Valencia orchard in May 2009 
Reference evapotranspiration

Reference evapotranspiration ( $\left(\mathrm{ET}_{\mathrm{O}}\right)$ was determined using the FAO PenmanMonteith equation (Allen et al. 1998) from weather data obtained from an AWS located on each farm (within $2 \mathrm{~km}$ of the orchards). The AWS at Groblersdal was located on an open stretch of mown, rain-fed grass and was $50 \mathrm{~m}$ west of natural vegetation, which consisted of sparse trees (2-3 $\mathrm{m}$ tall) and grasslands. There were buildings to the east, within $130 \mathrm{~m}$ of the AWS, and irrigated orchards within $300 \mathrm{~m}$ to the north. Under these fairly dry conditions, calculated $E T_{0}$ is likely to be slightly overestimated, as compared to calculations made using weather data collected over a reference surface (Allen 2008). The AWS at Citrusdal was located on the site of a recently top-worked ( $1 \mathrm{~m}$ height), ridged and drip irrigated orchard, with a short ground cover consisting of grass and weeds. It was 20 m east of an irrigated orchard with a height of $3 \mathrm{~m}$, which would have reduced wind speed and therefore $\mathrm{ET}_{\mathrm{o}}$ is likely to be slightly underestimated, as compared to standard conditions (Allen 2008). The weather parameters recorded were wind speed, solar radiation, temperature, relative humidity and rainfall. Quality assessment and quality control of the data was performed according to the procedures described by Allen (2008). The "upper" measured values of solar radiation $\left(R_{s}\right)$ fell routinely below the clear-sky short wave radiation $\left(R_{\text {so }}\right)$ curve for both weather stations and $R_{S}$ measurements were therefore adjusted upwards based on the average value of $R_{s} / R_{\text {so }}$ on clear days (Allen 2008).

Transpiration crop coefficients

Transpiration crop coefficients were determined from measured tree transpiration and reference evapotranspiration:

$$
K_{\mathrm{t}}=\frac{T}{E T_{o}}
$$

where $K_{\mathrm{t}}$ is the transpiration crop coefficient, $T$ is transpiration estimated from sap flow measurements and $\mathrm{ET}_{\mathrm{o}}$ is computed reference evapotranspiration. Monthly crop coefficients were calculated from monthly totals of measured daily orchard transpiration and $\mathrm{ET}_{\mathrm{o}}$. Monthly crop coefficients were calculated as citrus is an 
evergreen crop and significant changes in canopy size do not occur on a weekly basis.

Estimation of transpiration crop coefficients from fractional ground cover and crop height

The procedure described by Allen and Pereira (2009) was used to estimate transpiration crop coefficients in the three orchards from measurements of fractional ground cover, tree height and daily weather data. $K_{\mathrm{t}}$ was adjusted for variation in vegetative cover by using a density coefficient $\left(K_{d}\right)$ as follows:

$$
K_{\mathrm{t}}=K_{\mathrm{d}}\left(K_{\mathrm{t} \text { full }}\right)
$$

where $K_{\mathrm{t}}$ full is defined as the transpiration crop coefficient during peak plant growth for conditions having nearly full ground cover (or LAI > 3).

According to Allen et al. (1998), for large stand size (greater than about $500 \mathrm{~m}^{2}$ ), $K_{\mathrm{t}}$ full for use with $\mathrm{ET}_{\mathrm{o}}$ can be approximated as a function of mean plant height and adjusted for climate as:

$$
K_{\mathrm{t} \text { full }}=F_{\mathrm{r}}\left(\min (1.0+0.1 h, 1.20)+\left[0.04\left(u_{2}-2\right)-0.004\left(R H_{\min }-45\right)\right]\left(\frac{h}{3}\right)^{0.3}\right)
$$

where $F_{\mathrm{r}}[0-1]$ is a relative adjustment factor for stomatal control, $h$ is mean monthly plant height $(\mathrm{m}), u_{2}$ is average monthly wind speed $\left(\mathrm{m} \mathrm{s}^{-1}\right)$ at $2 \mathrm{~m}$ for a particular growth period and $R H_{\text {min }}$ is the average monthly minimum relative humidity in per cent. Parameter $F_{\mathrm{r}}$ applies a downward adjustment $\left(F_{r} \leq 1.0\right)$ if the vegetation exhibits more stomatal control on transpiration than is typical of most annual agricultural crops, a situation that is typical of citrus (Kriedemann and Barrs 1981). Allen and Pereira (2009) suggested the following calculation for $F_{\mathrm{r}}$ for full cover vegetation, based on the FAO Penman-Monteith equation and assuming full cover conditions: 


$$
F_{r} \approx \frac{\Delta+\gamma\left(1+0.34 u_{2}\right)}{\Delta+\gamma\left(1+0.34 u_{2} \frac{r_{l}}{100}\right)}
$$

where $r_{1}$ is mean leaf resistance for the vegetation in question $\left(\mathrm{s} \mathrm{m}^{-1}\right) ; \Delta$ is the slope of the saturation vapour pressure versus air temperature curve $\left(\mathrm{kPa}^{\circ} \mathrm{C}^{-1}\right)$ and $\mathrm{y}$ is the psychrometric constant $\left(\mathrm{kPa}^{\circ} \mathrm{C}^{-1}\right)$. For most annual agricultural crops the value of $r_{l}$ is $100 \mathrm{~s} \mathrm{~m}^{-1}$, which sets $F_{\mathrm{r}}$ to 1 . Allen and Pereira (2009) suggest a value of 420 $\mathrm{s} \mathrm{m}^{-1}$ for the initial and midseason periods and $150 \mathrm{~s} \mathrm{~m}^{-1}$ at the end of the season for citrus. Values of mean monthly $r_{1}$ for the study orchards were estimated by inverting Eq. 5, after solving for $F_{\mathrm{r}}$ by inverting Eq. 4, using known monthly values of $K_{\mathrm{t}}$ full. $K_{\mathrm{t}}$ full values were calculated using average monthly $K_{t}$ (Eq. 2) and $K_{d}$ values (Eq. 6), both determined from measured data, and inverting Eq. 3. Measurements of leaf resistance in the "Rustenburg" Navel orchard were performed with a SC-1 Leaf porometer (Decagon Device Inc, Pullman, WA, USA) on 5 sunlit leaves per tree instrumented with sap flow equipment. Measurements were made every hour from sunrise to sunset for a minimum of 3 days and an average was obtained for each measurement period.

The density factor $\left(K_{\mathrm{d}}\right)$ was determined according to Allen and Pereira (2009) as follows:

$$
K_{\mathrm{d}}=\min \left(1, M_{L} f_{\mathrm{c} \text { eff }}, f_{\mathrm{c} \mathrm{eff}}^{\left(\frac{1}{1+h}\right)}\right)
$$

where $f_{\mathrm{c} \text { eff }}$ is the effective fraction of ground covered or shaded by vegetation [0.011] near solar noon, $M_{L}$ is a multiplier on $f_{\mathrm{c} \text { eff }}$ and is an attempt to simulate hydraulic resistances within the plant and is expected to range between 1.5 and 2.0, with a value of 1.5 recommended for citrus (Allen and Pereira 2009). $f_{\mathrm{c}}$ eff was calculated as the ratio of tree canopy width to inter-row spacing or the ratio of ground shaded area by the crop at solar noon to the total area available to the tree, following Allen et al. (1998) in the "Delta" Valencia orchard with a north-south orientation. In the "Bahianinha" and „Rustenburg" Navel orchards, provision had to be made for row orientation. In these orchards, $f_{c}$ eff was calculated according to Allen et al. (1998) as follows: 


$$
f_{c \text { eff }}=\frac{f c}{\sin (\beta)} \leq 1
$$

where $f_{\mathrm{c}}$ is the observed fraction of soil surface that is covered by vegetation as seen from directly overhead. $f_{c}$ eff is usually calculated at solar noon, such that $\beta$ (mean elevation angle of the sun above the horizon during the period of maximum evapotranspiration) can be calculated as:

$$
\beta=\arcsin [\sin (\varphi) \sin (\delta)+\cos (\varphi) \cos (\delta)]
$$

where $\varphi$ is latitude and $\delta$ solar declination, both in radians.

Statistical analysis

The evaluation of model performance was done with the aid of statistical parameters including coefficient of determination $\left(R^{2}\right)$, mean absolute error (MAE), root of the mean square error (RMSE) and index of agreement (D) of Willmott (1982). Model performance was considered satisfactory when $R^{2}>0.8$, MAE $<20 \%$ and $D>0.8$ (de Jager 1994).

\section{Results and Discussion}

Transpiration in all orchards showed large day to day variation, which was largely determined by the prevailing climatic conditions, as seen from the ETo data (Fig. 4a, b and c). However, it is evident that even though the atmospheric evaporative demand was highest during summer in all three regions, there was no proportional increase in transpiration at this time. Furthermore, although higher atmospheric evaporative demands were observed in Citrusdal during the summer months (winter rainfall region), the "Rustenburg" Navels did not use proportionally more water compared to the orchards in Groblersdal (summer rainfall region), even though canopy size was similar. This has previously been noted by Kaufmann (1977), who observed that although evaporative demand was much higher under Arizona desert conditions, as compared to the humid conditions in Florida, citrus transpiration was very similar in summer in these two regions. 

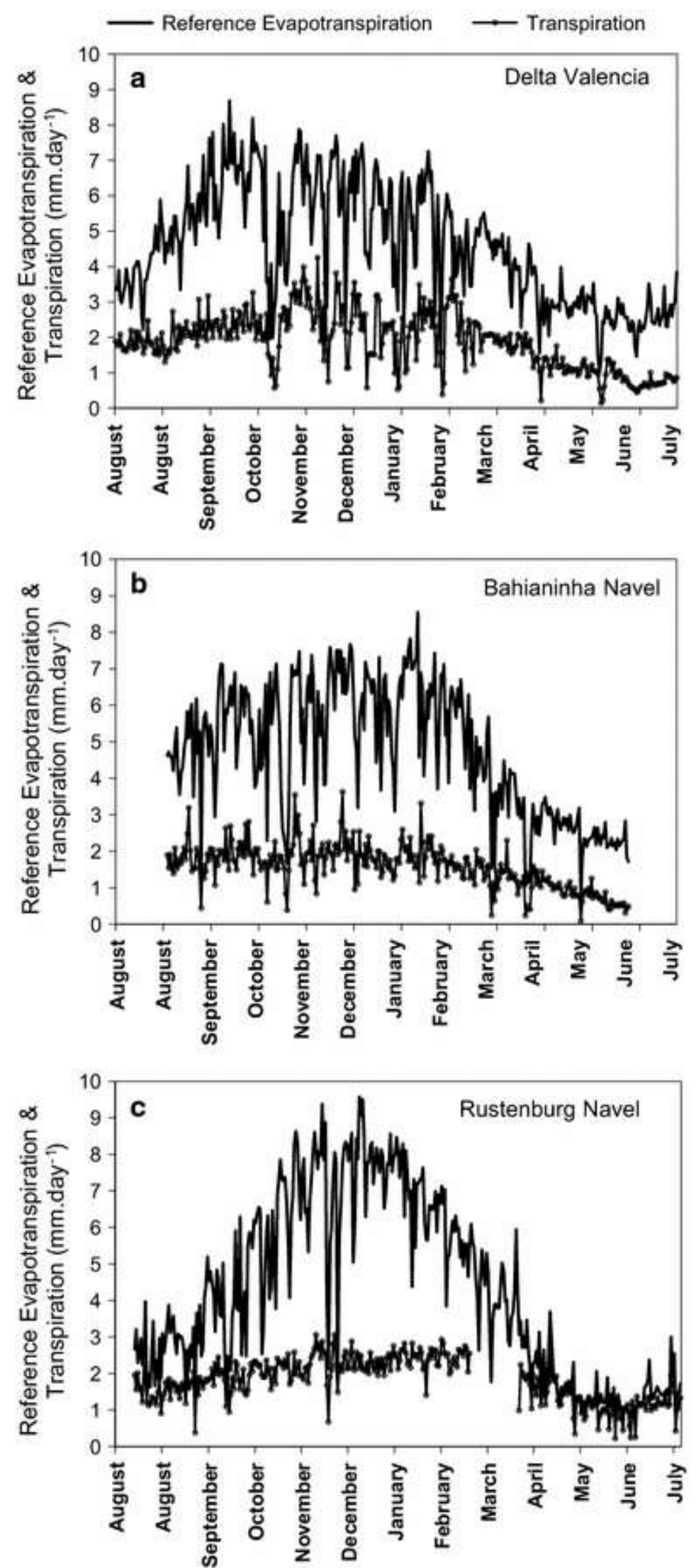

Fig. 4 : Daily transpiration $\left(\mathrm{mm} \mathrm{day}^{-1}\right)$ and reference evapotranspiration $\left(\mathrm{mm} \mathrm{day}^{-1}\right)$ for a the „Delta" Valencia orchard from 1 August 2008 to 31 July 2009, b the „Bahianinha"Navel orchard from 3 September 2009 to 30 June 2010 and c the „Rustenburg"Navel orchard from 13 August 2010 to 12 August 2011 (transpiration data from 18 March to 17 April 2011 is missing as a result of a power failure) 
Table 4 Summary of average canopy size for the three orchards and average transpiration $(T)$, transpiration crop coefficients $\left(K_{\mathrm{t}}\right)$, reference evapotranspiration ( $\left.E T_{0}\right)$ and vapour pressure deficit (VPD) for the summer and winter periods of measurements. $f_{\mathrm{c}}$ eff is the effective fraction of ground covered or shaded by the vegetation at solar noon

\begin{tabular}{|c|c|c|c|c|c|c|c|c|c|c|c|}
\hline \multirow[t]{2}{*}{$\begin{array}{l}\text { Rainfall } \\
\text { region }\end{array}$} & \multirow[t]{2}{*}{ Crop } & \multicolumn{2}{|c|}{ Canopy size } & \multicolumn{2}{|c|}{$\mathrm{T}\left(\mathrm{mm} \mathrm{day}^{-1}\right)$} & \multicolumn{2}{|c|}{$K_{\mathrm{t}}$} & \multicolumn{2}{|c|}{$\mathrm{ET}_{0}\left(\mathrm{~mm} \mathrm{day}^{-1}\right)$} & \multicolumn{2}{|c|}{ VPD (kPa) } \\
\hline & & Height (m) & $f_{c \text { eff }}$ & Summer & Winter & Summer & Winter & Summer & Winter & Summer & Winter \\
\hline Summer & Valencia & 4.1 & 0.60 & 2.30 & 1.16 & 0.43 & 0.38 & 5.75 & 2.57 & 1.37 & 1.16 \\
\hline Winter & Navel & 3.3 & 0.88 & 2.26 & 1.08 & 0.31 & 0.71 & 6.42 & 1.62 & 2.24 & 0.74 \\
\hline
\end{tabular}


Differences in transpiration between seasons and rainfall regions become more evident when averages for summer and winter are compared between the different rainfall regions (Table 4). In the summer rainfall region, despite large differences in average daily $\mathrm{ET}_{\mathrm{o}}$ during the year, the average $K_{\mathrm{t}}$ for both orchards remained relatively constant throughout the year, which agrees with the single crop coefficient for citrus suggested by Allen and Pereira (2009). However, in the winter rainfall region there was a significant difference in $K_{\mathrm{t}}$ values between the two seasons, with the winter $K_{\mathrm{t}}$ being significantly larger than the summer $K_{\mathrm{t}}$, as observed by García Petillo and Castel (2007) in Uruguay and Villalobos et al. (2013) in Spain. $K_{\mathrm{t}}$ values in this current study compare well to those reported by Villalobos et al. (2013), who reported summer $K_{\mathrm{t}}$ values ranging between 0.3 and 0.4 and in autumn between 0.4 and 0.6. The most obvious difference in $K_{\mathrm{t}}$ values between orchards was found in the winter months, where values were considerably higher in the winter rainfall region, which is most likely attributable to the lower average vapour pressure deficit (VPD) and higher average transpiration rates at this time in this region (Table 4). Kriedemann and Barrs (1981) and Oguntunde et al. (2007) both reported that VPD is the dominant regulator of transpiration in citrus, when trees are well-watered, with transpiration decreasing with an increase in VPD. VPD during the winter months in the winter rainfall region averaged $0.74 \mathrm{kPa}$, whilst in the orchards in the summer rainfall region, VPD averaged $1.11 \mathrm{kPa}$. The lower VPD was also reflected in lower $\mathrm{ET}_{\mathrm{o}}$ in winter in the winter rainfall region than in the summer rainfall region.

Whilst this kind of information is of significance to the commercial growers on whose farms the research was conducted, it is not always applicable and readily transferrable to many other regions within South Africa or across citrus growing regions the world over, or even for different seasons. However, direct measurements of transpiration, using a sap flow technique, are an improvement on traditional soil water balance approaches, as these have proved problematic as a result of the two or three dimensional variability in soil water components found in hedgerow crops under micro-irrigation systems (Cohen 1991; Rana and Katerji 2000; Annandale et al. 2003; Testi et al. 2006; Villalobos et al. 2009) and therefore presents a valuable data set for modelling citrus water use. The relatively simple and convenient crop coefficient approach of Allen et al. (1998) relates water use of various crops to evapotranspiration from a well-watered hypothetical short grass reference surface. 
However, reports on crop coefficients from different citrus orchards in different parts of the world have yielded very different crop coefficients (Table1). The adjustment of crop coefficients following the procedure of Allen and Pereira (2009) from measurements of canopy dimensions could therefore prove extremely useful in predicting water use in different orchards and citrus growing regions.

$K_{\mathrm{t}}$ values for the measurement orchards were initially derived using parameters for citrus provided by Allen and Pereira (2009), where the value for $M_{L}$ was set to 1.5, apparent effective $r_{1}$ for the initial and midseason periods was $420 \mathrm{~s} \mathrm{~m}^{-1}$ and $r_{l}$ at the end of the season was $150 \mathrm{~s} \mathrm{~m}^{-1}$, and measured canopy dimensions and weather data were used. However, these transpiration coefficients ( $K_{\mathrm{t}}$ Allen and Pereira) did not compare well with the measured $K_{\mathrm{t}}$ values from the three orchards, and were at times in the season higher than the FAO-56 $K_{\mathrm{cb}}$ values for citrus given by Allen and Pereira (2009) (Fig. $5 \mathrm{a}, \mathrm{b}$ and $\mathrm{c}$ ). If derived $K_{\mathrm{t}}$ values using the published fixed values of $r_{\mathrm{l}}$, (Estimated transpiration from $K_{\mathrm{t}}$ Allen and Pereira) were to be applied over a season, they would have resulted in a $94 \%$ over estimation of transpiration in the "Delta" Valencia orchard, a $127 \%$ overestimation in the "Bahianinha" Navel orchard and a 95\% overestimation in the "Rustenburg" Navel orchard (Fig. 6 a, b and c).

The fixed parameters for citrus orchards given by Allen and Pereira (2009) were therefore not able to generate accurate transpiration crop coefficients for the orchards in this study, where specific orchard inputs were effective fractional cover, height and monthly averaged daily weather data. The overestimation of transpiration 

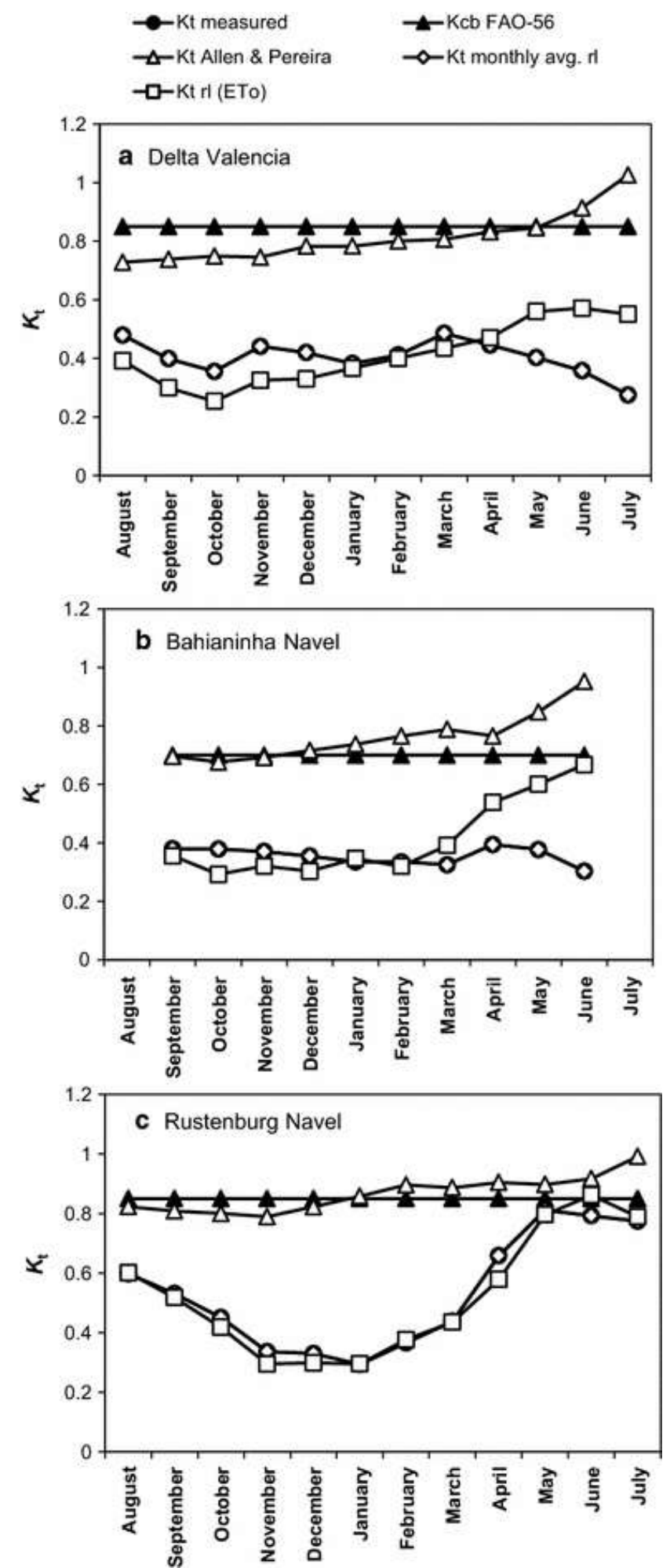

Fig. 5 : Derived monthly transpiration crop coefficients $\left(K_{t}\right)$ for a the „Delta" Valencia orchard, $b$ „Bahianinha" Navel orchard and c „Rustenburg" Navel orchard. Transpiration crop coefficients were determined using measured transpiration ( $\mathrm{K}_{\mathrm{t}}$ measured), the method described in Allen and Pereira (2009) using the parameters given for citrus ( $\mathrm{K}_{t}$ Allen and Pereira), using estimates of monthly average $r_{1}$ values from transpiration data $\left(K_{t}\right.$ monthly avg. $\left.r_{1}\right)$ and using $r_{1}$ estimated from the relationship with $E T_{\circ}\left(K_{t} r_{1}\left(E T_{o}\right)\right)$. Also shown are FAO-56 standardised basal crop coefficients $\left(K_{c b}\right.$ FAO-56) for a citrus orchard with $70 \%$ canopy cover („Delta" and „Rustenburg" orchards) and $50 \%$ ground cover (,Bahianinha" orchard), all with no active ground cover, as given by Allen and Pereira (2009) 

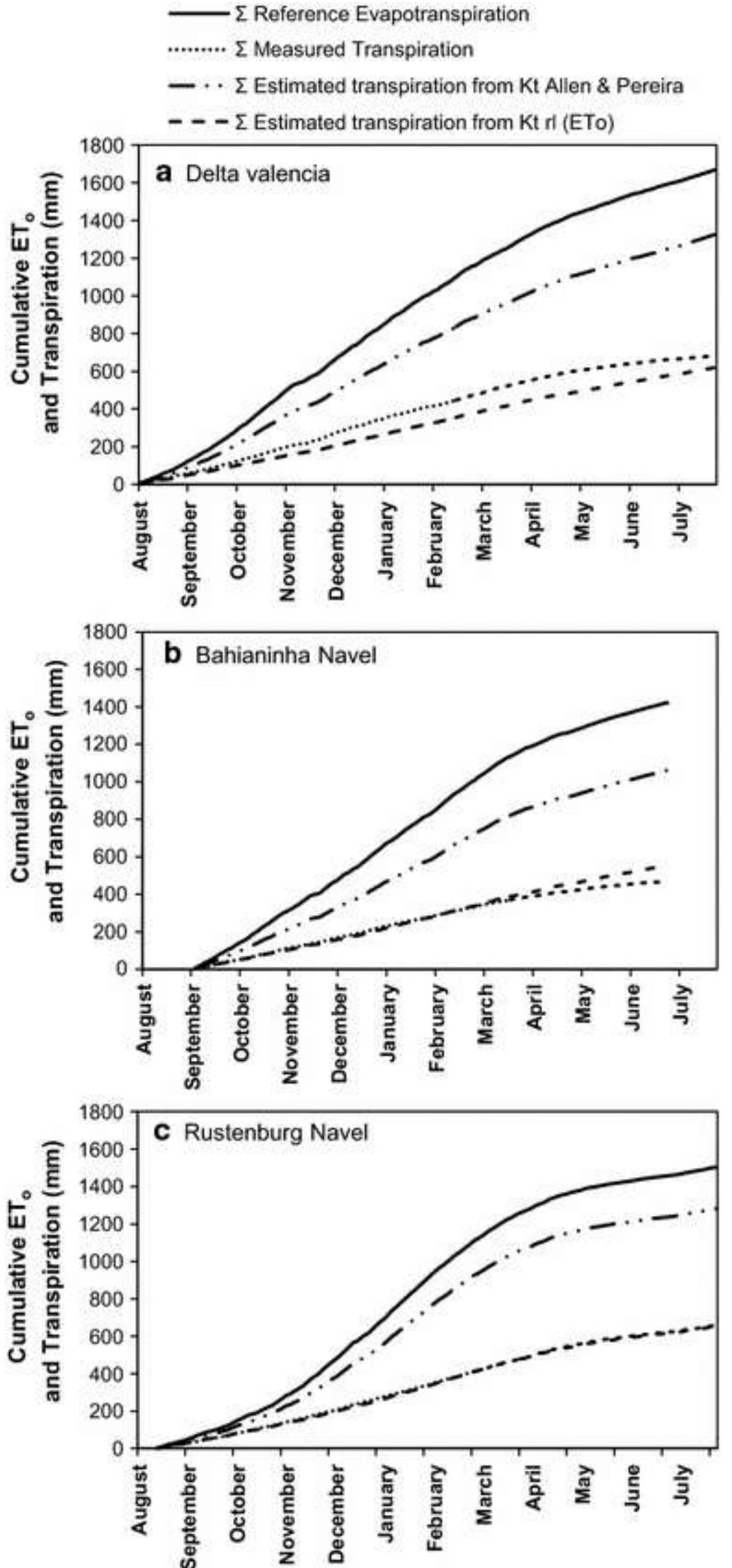

Fig. 6 : Cumulative ET o, measured transpiration and transpiration estimated from the derived transpiration coefficients in a the „Delta" Valencia orchard from 1 August 2008 to 31 July 2009, b the „Bahianinha" Navel orchard from 3 September 2009 to 30 June 2010 and c the „Rustenburg Navel orchard from 13 August 2010 to 12 August 2011 
coefficients and crop water use using the given citrus parameters, is likely a reflection of the greater stomatal control of transpiration in citrus than in most other crops, which is attributed to high resistances to water transport within the plant (van Bavel et al. 1967; Kriedemann and Barrs 1981; Sinclair and Allen 1982). Whilst Allen and Pereira (2009) account for this by including their $F_{\mathrm{r}}$ parameter, which is used as a downward adjustment on crop coefficients for crops which exhibit more stomatal control on transpiration than most other agricultural crops, the $r_{\uparrow}$ value of $420 \mathrm{~s} \mathrm{~m}^{-1}$ suggested by the authors may be too low, especially during hot summer months, when VPD increases. It is suggested that a more appropriate value for $r_{1}$ can be estimated for the determination of $F_{r}$ by inverting Eq. 5, after solving for $F_{r}$ by inverting Eq. 4, using known values of $K_{\mathrm{t}}$ full (Allen and Pereira 2009). Monthly $K_{\mathrm{t}}$ full values for this study were obtained by scaling measured monthly $K_{\mathrm{t}}$ values with the density coefficient ( $K_{d}$, Eq. 3 ), and were used to calculate a mean monthly $r_{\text {. }}$ Although these values may only be useful for re-use in Eq. 5, it is clear that mean monthly estimated $r_{1}$ (Fig. 7) is not constant throughout the season and varies with leaf age and climatic conditions, as found by van Bavel et al. (1967). As a result of the greater degree of stomatal control of transpiration in citrus, which is more evident at high VPDs (Sinclair and Allen 1982), leaf resistance in all three orchards increased in the summer months, which results in a disproportionate increase in $E T_{0}$ relative to transpiration and therefore a lowering of the appropriate crop coefficient.

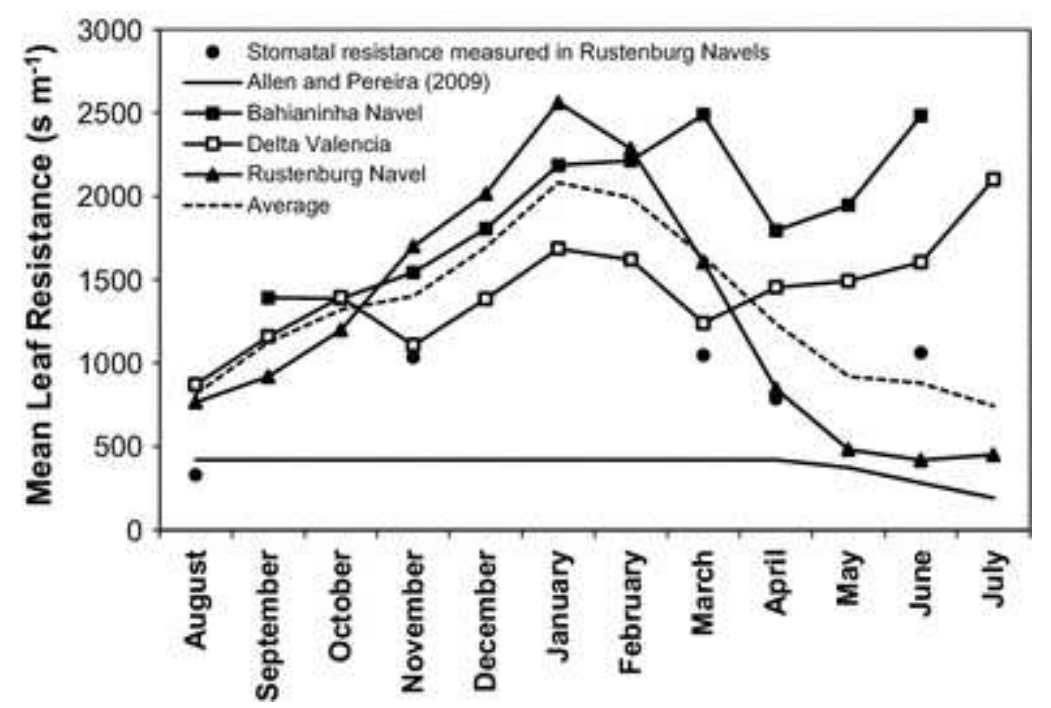

Fig. 7 : Monthly mean leaf resistances from the three citrus orchards calculated using the procedure outlined in Allen and Pereira (2009), compared with the value suggested by Allen and Pereira (2009) for citrus and daily stomatal resistance measured in the „Rustenburg"Navel orchard in Citrusdal 
As the calculated monthly average $r_{\mathrm{l}}$ values were derived directly from measured $K_{\mathrm{t}}$ values ( $K_{\mathrm{t}}$ measured), it is not surprising that they provided very good estimates of $K_{\mathrm{t}}$ $\left(K_{\mathrm{t}}\right.$ monthly avg. $\left.r_{1}\right)$ for the three orchards (Fig. $5 \mathrm{a}$, b and c), with the two plots sitting perfectly on top of one another. This indicates that a change in leaf resistance in a citrus orchard over the season needs to be taken into account. Unlike Allen and Pereira (2009) suggested, resistance in the study orchards did not decline at the end of the season, and in Groblersdal, $r_{1}$ increased at this point. Whilst it is acknowledged that these $r_{\text {I }}$ values contain artifacts of the $K_{\mathrm{t}}$ full estimates, weather data error and the constructs of Eq. 4 and Eq. 5 and should only be used with confidence for the estimation of $F_{\mathrm{r}}$ (Allen and Pereira 2009), a comparison of these resistance values (ranging from 419 to $2694 \mathrm{~s} \mathrm{~m}^{-1}$ ) with published measured data indicates that leaf and canopy resistances higher than $420 \mathrm{~s} \mathrm{~m}^{-1}$ are routinely found in citrus. In the summer rainless months in Israel daily leaf resistances in Shamouti orange varied from 500 to $2000 \mathrm{~s} \mathrm{~m}^{-1}$ (Cohen and Cohen 1983) and in winter in Zimbabwe, resistances in young Navel orange trees varied from 200 to $8280 \mathrm{~s} \mathrm{~m}^{-1}$ (Dzikiti et al. 2007). Pérez-Pérez et al. (2008) also reported stomatal resistances ranging between 295 and $830 \mathrm{~s} \mathrm{~m}^{-1}$ in oranges throughout the fruit growth period in Southern Spain. However, average daily stomatal resistance, measured in the various citrus orchards in Citrusdal, was between 300 and $1000 \mathrm{~s} \mathrm{~m}^{-1}$ (Fig. 7), which was considerably lower than the $r_{1}$ values of between 530 and $2694 \mathrm{~s} \mathrm{~m}^{-1}$ for this period, but generally the trend was very similar. The $r_{\text {l }}$ values in Fig. 7 thus seem to be a little higher than actual $r_{1}$ could be expected to be in a citrus orchard, and may therefore be slightly biased by the procedure outlined by Allen and Pereira (2009), indicating that measured leaf resistances could potentially underestimate crop coefficients when used in Eq. 5. This requires further investigation, especially during the hot summer months, but it is clear that $r_{1}$ values higher than $420 \mathrm{~s} \mathrm{~m}^{-1}$ are routinely found in citrus and seasonal variation must be taken into account.

Whilst calculating mean $r_{\mathrm{l}}$ values resulted in the accurate estimation of $K_{\mathrm{t}}$ values in the three orchards, it is the estimation of mean $r_{l}$, without measured transpiration, that really hinders the ease with which this approach can be used to accurately estimate crop coefficients for different citrus orchards. In order to make this approach more transferrable, the parameterization of $r_{1}$ was attempted for the Citrusdal site with climatic data in the $2010 / 11$ season, to determine if there was a reproducible 
relationship between $r_{1}$ and a routinely measured weather variable, such as relative humidity, VPD or $\mathrm{ET}_{\mathrm{o}}$. The most reproducible empirical relationship on a monthly basis was found between $\mathrm{ET}_{\mathrm{o}}\left(\mathrm{mm} \mathrm{day}^{-1}\right)$ and mean estimated $r_{1}\left(\mathrm{~s} \mathrm{~m}^{-1}\right)$ (Fig. 8),

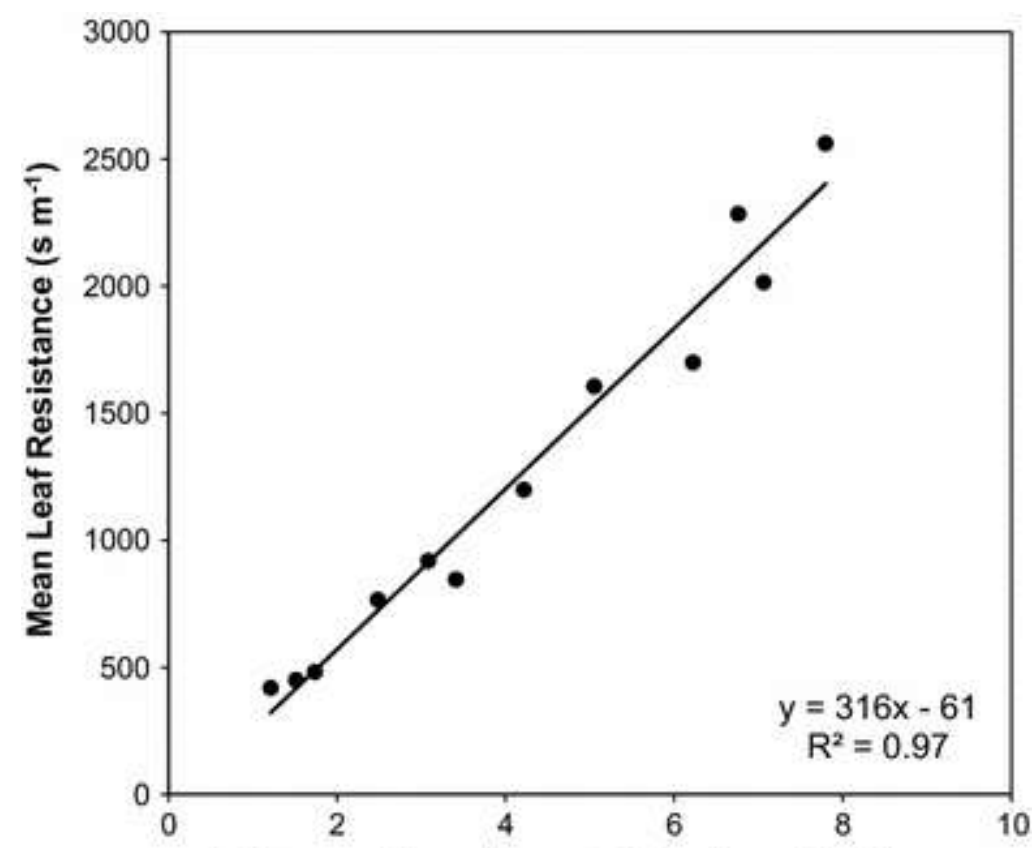

Reference Evapotranspiration ( $\left.\mathrm{mm}_{\text {day }}{ }^{-1}\right)$

Fig. 8 : Relationship between mean leaf resistance and reference evapotranspiration (ET o) for the „Rustenburg"Navel orchard in the 2010/2011 season

where $r_{1}=316 \mathrm{ET}_{0}-61$ described the relationship with an excellent coefficient of determination $\left(R^{2}\right)$ of 0.97 . When comparing seasonal estimates of transpiration based on estimated $K_{\mathrm{t}}$ values $\left(K_{\mathrm{t}} r_{\mathrm{l}}\left(\mathrm{ET}_{\mathrm{o}}\right)\right.$ ) (Figs $5 \mathrm{a}$, b and $\mathrm{c}$ ) from this relationship, transpiration was underestimated by $0.1 \%$ in the $2010 / 11$ season and by $11 \%$ in the $2011 / 12$ season in the „Rustenburg" Navels, and underestimated by $9 \%$ in the "Delta" Valencia orchard and overestimated by $18 \%$ in the "Bahianinha" Navel orchard (Fig. 6 and Fig. 9). The performance of the model, as determined by statistical parameters, was good for the two seasons in the orchards in Citrusdal, as the MAE was less than $20 \%$ and D greater than 0.8 . It did not, however, perform as well in the orchards in the summer rainfall region with an MAE of 23 and $24 \%$ and D of 0.55 and 0.63. However, considering the empirical nature of the relationship between $r_{1}$ and $\mathrm{ET}_{\mathrm{o}}$ this exceeded expectations and provided reasonable estimates on a seasonal basis. In the „Delta" Valencia and „Bahianinha" orchards, transpiration was underestimated at the beginning of the season and overestimated at the end of the 


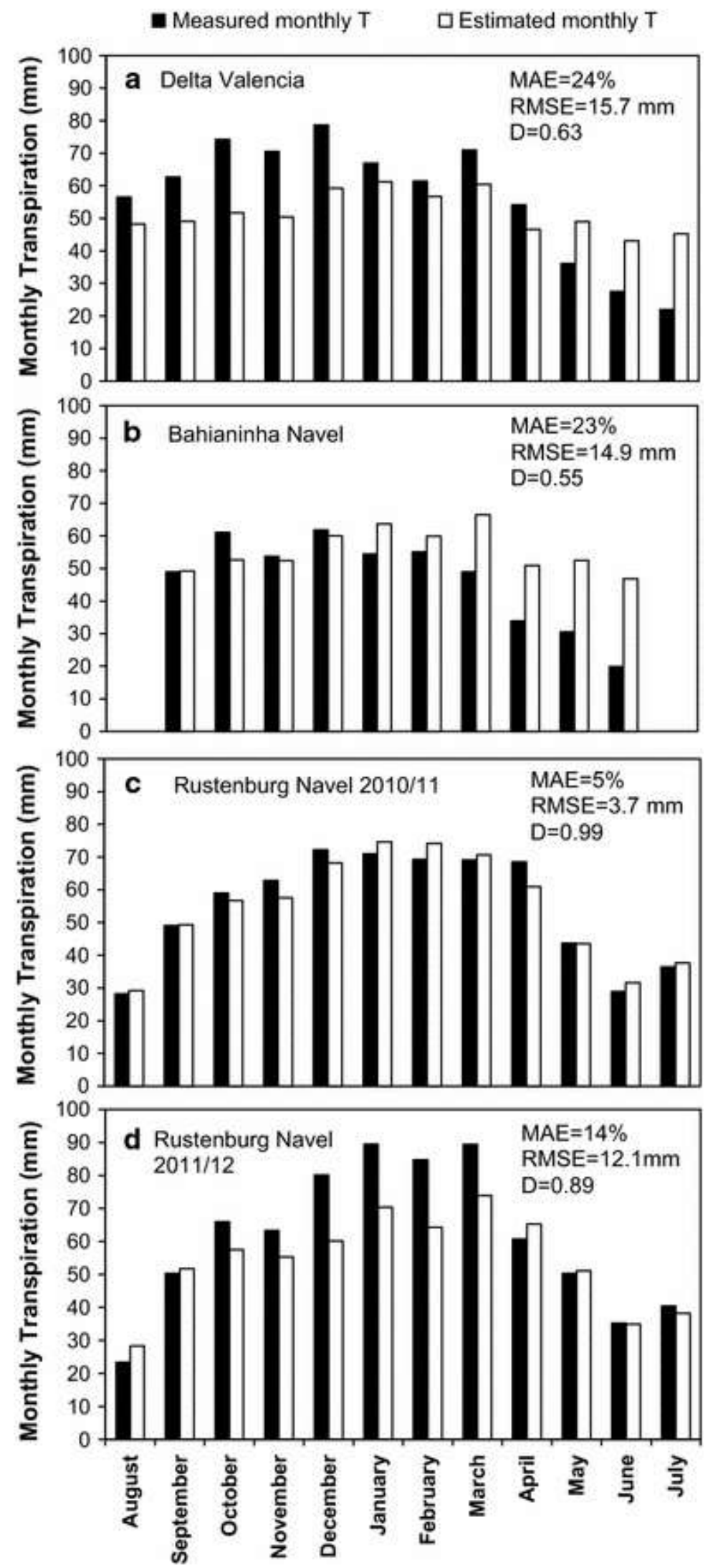

Fig. 9 : Comparison between monthly measured and estimated transpiration using $\mathrm{K}_{\mathrm{t}}$ values derived from mean leaf resistance, estimated from the relationship between reference evapotranspiration and mean leaf resistance, for the a "Delta" Valencia orchard, b „Bahianinha" Navel orchard, c „Rustenburg" Navel orchard in the 2010/2011 season and d ,Rustenburg" Navel orchard in the 2011/2012 season. MAE is mean absolute error, RMSE is root of the mean square error and D is the index of agreement of Willmott (1982) 
season (Fig. 9a). The underestimation at the start of the season was more pronounced in the "Delta" Valencia orchard, whilst the overestimation at the end of the season was more pronounced in the „Bahianinha" Navel orchard, (Fig. 9b). In the „Rustenburg" Navel orchard, in the 2010/11 season, good estimates of water use were obtained throughout the season (Fig. 9c). However, in the subsequent 2011/12 season, water use was underestimated during the peak water use period from October to March (Fig. 9d), but model performance was still satisfactory (MAE=14\% and $\mathrm{D}=0.89$ ).

The use of a simple empirical relationship between $\mathrm{ET}_{\mathrm{o}}$ and $r_{1}$, together with the procedure outlined by Allen and Pereira (2009), provided good seasonal transpiration estimates in the study orchards, implying that this method could be used for irrigation planning purposes and water licensing. However, the inability to predict water use accurately on a monthly basis for most of the season limits the use of this procedure for irrigation scheduling, which will require more reliable estimates of $r_{1}$. This is not unexpected, as stomatal conductance is known to be regulated by a number of factors, which includes radiant flux energy, ambient $\mathrm{CO}_{2}$ concentration, leaf to air vapour pressure deficit, leaf temperature, leaf water status, and hydraulic limitations to leaf water supply (Jarvis 1976; Sperry et al. 2002) and it is usually a combination of these factors that determines stomatal conductance. This creates uncertainty when only using climatic data to predict stomatal responses. In this respect, reduced sink activity or accumulation of carbohydrates in leaves could also lead to decreases in stomatal conductance (Iglesias et al. 2002; Syvertsen et al. 2003; Duan et al. 2008), which may be a contributing factor to the increased leaf resistance in the Groblersdal orchards at the end of the season, as both these orchards experienced lower than average yields during the monitoring period. As a result of the reduced number of fruit on trees, and therefore sink strength, feedback inhibition of photosynthesis through carbohydrate accumulation in leaves may have occurred. Although Nebauer et al. (2013) attributed the lack of difference in photosynthetic rates between high and low yielding citrus trees, in alternate bearing cycles, to an unsaturable sink in the root system of perennial fruit trees, their evidence is not compelling enough to suggest that changes in fruit load have no impact on overall tree sink demand and canopy conductance. Further research is therefore required to determine the link between yield and water use, as this has 
implications for predicting seasonal water use. The solution for better prediction of leaf resistances may be to use more mechanistic models which can predict canopy conductance based on canopy size, environmental variables and sink strength or potential yield. Similar approaches have been undertaken by Oguntunde et al. (2007) and Villalobos et al. (2009; 2013) and have shown some promise, but the ability of these models to predict citrus water use need to be verified in orchards with different canopy sizes and in different climatic regions

Alternatively, a combination of a crop coefficient approach, together with the concept of a maximum transpiration rate (Sinclair and Allen 1982) needs to be considered, where it is recognised that the tree is only able to supply a certain maximum amount of water to the atmosphere, irrespective of the atmospheric demand. This is mainly attributed to high internal resistances to water movement in citrus (Cohen and Cohen 1983; Syvertsen and Graham 1985; Rodríguez-Gamir et al. 2010). If using such a model it will be important to be able to determine what this maximum transpiration rate would be for a certain sized canopy, which in itself is not a trivial matter and may also be influenced by sink source relationships and by rootstock choice. Ultimately, due to the greater stomatal control of transpiration in citrus than in most other crops, crop coefficients that are constant or are based on parameters that are constant are not suitable for accurate predictions of water use, as crop coefficient models assume atmospheric demand-limited conditions and transpiration in citrus is often water supply-limited, even in well watered orchards. In order to obtain accurate water use estimates for citrus using crop coefficients, the crop coefficient often needs to be decreased during the hottest time of the year when VPD increases. This can be done by using a dynamic estimate of leaf resistance which gives reasonable estimates of water use for much of the season. However, more mechanistic models which are able to capture the control of transpiration through canopy conductance in citrus varieties, and other crops displaying similar stomatal control, such as olive and macadamia, should be considered for improved water management.

\section{Acknowledgements}

This is a solicited project, initiated, managed and funded by South Africa"s Water Research Commission (Project K5/1770, Water use of fruit tree orchards), with cofunding from the South African National Department of Agriculture, Forestry and 
Fisheries. We are also grateful to Schoeman Boerdery for the use of their orchard, in particular J Burger, H Schoeman and B du Toit and to Patrysberg Farm, in particular $\mathrm{C}$ Junius and $\mathrm{J}$ Toerien.

\section{References}

Allen RG, Pereira LS (2009) Estimating crop coefficients from fraction of ground cover and height. Irrig Sci 28:17-34

Allen RG, Pereira LS, Raes D, Smith M (1998) Crop evapotranspiration: guidelines for computing crop water requirements, Irrigation and Drainage Paper 56. United Nations FAO, Rome http://www.fao.org/docrep/X0490E/X0490E00.htm

Allen RG (2008) Quality assessment of weather data and micrometeological flux impacts on evapotranspiration calculation. J Agric Meteorol 64:191-204

Allen RG, Pereira LS, Howell TA, Jensen ME (2011a) Evapotranspiration information reporting: I. Factors governing measurement accuracy. Agric Water Manage 98:899-920

Allen RG, Pereira LS, Howell TA, Jensen ME (2011b) Evapotranspiration information reporting: II. Recommended documentation. Agric Water Manage 98:921-929

Alves J, Folegatti MV, Parsons LR, Bandaranayake W, da Silva CR, da Silva TJA, Campeche LFSM (2007) Determination of the crop coefficient for grafted "Tahiti" lime trees and soil evaporation coefficient of Rhodic Kandiudalf clay soil in Sao Paulo, Brazil. Irrig Sci 25:419-428

Annandale J, Jovanovic N, Campbell G, Du Sautoy N, Benade N (2003) A twodimensional water balance model for micro-irrigated hedgerow tree crops. Irrig Sci 22:157-170

Annandale J, Stockle C (1994) Fluctuation of crop evapotranspiration coefficients with weather: a sensitivity analysis. Irrig Sci 15:1-7

Baldocchi D (1997) Flux footprints within and over forest canopies. Bound -Layer Meteorol 85:273-292

Burgess SSO, Adams MA, Turner NC, Beverly CR, Ong CK, Khan AAH, Bleby TM (2001) An improved heat pulse method to measure low and reverse rates of sap flow in woody plants. Tree Physiol 21:589-598

Castel JR, Bautista I, Ramos C, Cruz G (1987) Evapotranspiration and irrigation efficiency of mature orange orchards in Valencia (Spain). Irrig Drain Syst 1:205217 
Castel J (1997) Evapotranspiration of a drip-irrigated Clementine citrus tree in a weighing lysimeter. Acta Hort 449:91-98

Cohen S, Cohen Y (1983) Field studies of leaf conductance response to environmental variables in citrus. J Appl Ecol 20:561-570

Cohen $Y$ (1991) Determination of orchard water requirement by a combined trunk sap flow and meteorological approach. Irrig Sci 12:93-98

Conceição N and Ferreira M (2008) Combination of sap flow and eddy covariance techniques to obtain long term transpiration in a pear orchard. Acta Horticulturae 846:53-60

de Jager J (1994) Accuracy of vegetation evaporation ratio formulae for estimating final wheat yield. Water SA 20:307-314

Duan W, Fan PG, Wang LJ, Li WD, Yan ST, Li SH (2008) Photosynthetic response to low sink demand after fruit removal in relation to photoinhibition and photoprotection in peach trees. Tree Physiol 28:123-132

Dzikiti S, Steppe K, Lemeur R, Milford J (2007) Whole-tree level water balance and its implications on stomatal oscillations in orange trees [Citrus sinensis(L.) Osbeck] under natural climatic conditions. J Exp Bot 58:1893-1901

Fernández J, Palomo M, Dıaz-Espejo A, Clothier B, Green S, Girón I, Moreno F (2001) Heat-pulse measurements of sap flow in olives for automating irrigation: tests, root flow and diagnostics of water stress. Agric Water Manage 51:99-123

García Petillo M, Castel J (2007) Water balance and crop coefficient estimation of a citrus orchard in Uruguay. Span J Agric Res 5:232-243

Giorio P, Giorio G (2003) Sap flow of several olive trees estimated with the heatpulse technique by continuous monitoring of a single gauge. Environ Exp Bot 49:9-20

Green G, Moreshet S (1979) An analysis of seasonal water use characteristics of Valencia orange trees in the Sundays River Valley. Crop Prod 8:179-183

Green S, Clothier B (1988) Water use of kiwifruit vines and apple trees by the heatpulse technique. J Exp Bot 39:115-123

Hoffman GJ, Oster JD, Alves WJ (1982) Evapotranspiration of mature orange trees under drip irrigation in an arid climate. Trans Am Soc Agric Eng 25:992-996

Horst T, Weil J (1992) Footprint estimation for scalar flux measurements in the atmospheric surface layer. Bound -Layer Meteorol 59:279-296

Hultine KR, Nagler PL, Morino K, Bush SE, Burtch KG, Dennison PE, Glenn EP, Ehleringer JR (2010) Sap flux-scaled transpiration by tamarisk (Tamarix spp.) 
before, during and after episodic defoliation by the saltcedar leaf beetle (Diorhabda carinulata). Agric For Meteorol 150:1467-1475

Iglesias DJ, Lliso I, Tadeo FR, Talon M (2002) Regulation of photosynthesis through source: sink imbalance in citrus is mediated by carbohydrate content in leaves. Physiol Plantarum 116:563-572

Jarvis $P$ (1976) The interpretation of the variations in leaf water potential and stomatal conductance found in canopies in the field. Philos Trans Roy Soc Lond Ser B: Biol Sci 273:593-610

Kaufmann M (1977) Citrus-a case study of environmental effects on plant water relations. Proc Int Soc Citric (Orlando) 1:52-57

Köstner B, Schulze E, Kelliher F, Hollinger D, Byers J, Hunt J, McSeveny T, Meserth R, Weir P (1992) Transpiration and canopy conductance in a pristine broadleaved forest of Nothofagus: an analysis of xylem sap flow and eddy correlation measurements. Oecologia 91:350-359

Kriedemann P, Barrs H (1981) Citrus orchards. In: Kozlowski TT (ed) Water Deficits and Plant Growth, Academic Press, New York, pp 325-417

Marin FR, Angelocci LR (2011) Irrigation requirements and transpiration coupling to the atmosphere of a citrus orchard in Southern Brazil. Agric Water Manage 98:1091-1096

Marshall D (1958) Measurement of sap flow in conifers by heat transport. Plant Physiol 33:385-396

Naor A, Naschitz S, Peres M, Gal Y (2008) Responses of apple fruit size to tree water status and crop load. Tree Physiol 28:1255-1261

Nebauer SG, Arenas C, Rodríguez-Gamir J, Bordón Y, Fortunato-Almeida A, Monerri C, Guardiola JL, Molina RV (2013) Crop load does not increase the photosynthetic rate in Citrus leaves under regular cropping conditions. A study throughout the year. Sci Hortic 160:358-365

Oguntunde PG, van de Giesen N, Savenije HHG (2007) Measurement and modelling of transpiration of a rain-fed citrus orchard under subhumid tropical conditions. Agric Water Manage 87:200-208

Pérez-Pérez J, Romero P, Navarro J, Botía P (2008) Response of sweet orange cv "Lane late" to deficit irrigation in two rootstocks. I: water relations, leaf gas exchange and vegetative growth. Irrig Sci 26:415-425

Pernice F, Motisi A, Rossi F, Georgiadis T, Nardino M, Fontana G, Dimino G, Drago A (2008) Micrometeorological and sap flow measurement of water vapour exchanges in olive: scaling up from canopy to orchard. Acta Hort 846:159-166 
Poblete-Echeverría C, Ortega-Farias S, Zuñiga M, Fuentes S (2012) Evaluation of compensated heat-pulse velocity method to determine vine transpiration using combined measurements of eddy covariance system and microlysimeters. Agric Water Manage 109:11-19

Rana G, Katerji N, de Lorenzi F (2005) Measurement and modelling of evapotranspiration of irrigated citrus orchard under Mediterranean conditions. Agric For Meteorol 128:199-209

Rana G, Katerji N (2000) Measurement and estimation of actual evapotranspiration in the field under Mediterranean climate: a review. Eur J Agron 13:125-153

Rodríguez-Gamir J, Intrigliolo DS, Primo-Millo E, Forner-Giner M (2010) Relationships between xylem anatomy, root hydraulic conductivity, leaf/root ratio and transpiration in citrus trees on different rootstocks. Physiol Plant 139:159169

Rogers J, Allen L, Calvert D (1983) Evapotranspiration from a humid-region developing citrus groves with grass cover. Trans ASAE 26:1778-1783

Sinclair T, Allen L (1982) Carbon dioxide and water vapour exchange of leaves on field-grown citrus trees. J Exp Bot 33:1166-1175

Smith DM, Allen SJ (1996) Measurement of sap flow in plant stems. J Exp Bot 47:1833-1844

Snyder RL, O'Connell MG (2007) Crop coefficients for microsprinkler-irrigated, cleancultivated, mature citrus in an arid climate. J Irrig Drain Eng 133:43-52

Sperry J, Hacke U, Oren R, Comstock J (2002) Water deficits and hydraulic limits to leaf water supply. Plant, Cell Environ 25:251-263

Syvertsen J, Goñi C, Otero A (2003) Fruit load and canopy shading affect leaf characteristics and net gas exchange of "Spring" navel orange trees. Tree Physiol 23:899-906

Syvertsen J, Graham J (1985) Hydraulic conductivity of roots, mineral nutrition, and leaf gas exchange of citrus rootstocks. J Am Soc Hort Sci 119:865-869

Testi L, Villalobos F, Orgaz F (2004) Evapotranspiration of a young irrigated olive orchard in southern Spain. Agric For Meteorol 121:1-18

Testi L, Villalobos F, Orgaz F, Fereres E (2006) Water requirements of olive orchards: I simulation of daily evapotranspiration for scenario analysis. Irrig Sci 24:69-76

Van Bavel C, Newman J, Hilgeman R (1967) Climate and estimated water use by an orange orchard. Agric Meteorol 4:27-37 
Villalobos FJ, Testi L, Moreno-Perez MF (2009) Evaporation and canopy conductance of citrus orchards. Agric Water Manage 96:565-573

Villalobos FJ, Testi L, Orgaz F, García-Tejera O, Lopez-Bernal A, González-Dugo MV, Ballester-Lurbe C, Castel JR, Alarcón-Cabañero JJ, Nicolás-Nicolás E, Girona J, Marsal J, Fereres E (2013) Modelling canopy conductance and transpiration of fruit trees in Mediterranean areas: A simplified approach. Agric For Meteorol 171-172:93-103

Water Research Commission (2008) Knowledge Review 2007/2008 - Knowledge for growth and development. WRC, Pretoria

Williams D, Cable W, Hultine K, Hoedjes J, Yepez E, Simonneaux V, Er-Raki S, Boulet G, De Bruin H, Chehbouni A (2004) Evapotranspiration components determined by stable isotope, sap flow and eddy covariance techniques. Agric For Meteorol 125:241-258

Willmott CJ (1982) Some comments on the evaluation of model performance. Bull Am Meteorol Soc 63:1309-1313 